\title{
HUBUNGAN DUKUNGAN KELUARGA DENGAN TINGKAT KECEMASAN IBU HAMIL MENGHADAPI PROSES PERSALINAN
}

\section{THE RELATIONSHIP OF FAMILY SUPPORT WITH ANXIETY LEVEL OF PREGNANT MOTHERS FACING THE DELIVERY PROCESS}

\author{
Ira Kartika ${ }^{1^{*}}$, Ida Suryani ${ }^{2}$, Tiara Putri Claudya ${ }^{3}$ \\ 1,2,3 STIKes Dharma Husada, Indonesia \\ Jl. Terusan Jakarta No.75, Cicaheum, Kec. Kiaracondong, Kota Bandung, 40282, Indonesia \\ *E-mail corresponding: irakartika45@yahoo.co.id
}

(Diterima: September 2021; disetujui Oktober 2021; dipublish November 2021)

\begin{abstract}
ABSTRAK
Rasa cemas menghadapi proses persalinan menduduki peringkat teratas yang paling sering dialami oleh ibu hamil dalam menghadapi kehamilan dan persalinan, salah satu cara mengurangi kecemasan pada ibu hamil adalah dukungan keluarga. Kurangnya dukungan keluarga yang mengakibatkan kecemasan pada ibu hamil bisa berakibat bayi lahir prematur, anak akan kesulitan belajar, hiperaktif, atau bahkan anak menjadi autisme Penelitian ini bertujuan untuk mengetahui hubungan dukungan keluarga dengan tingkat kecemasan ibu hamil menghadapi proses persalinan di PMB Bd. C Kota Bandung. Penelitian menggunakan metode penelitian survey analitik dengan pendekatan cross sectional, dengan teknik sampel accidental sampling, yang menggunakan instrumen kuesioner. Hasil penelitian menunjukkan bahwa rata-rata hubungan dukungan keluarga dengan tingkat kecemasan ibu hamil menghadapi proses persalinan di PMB Bd. C Kota Bandung dengan nilai $\mathrm{P}$ value $>0,05$. Penelitian ini menunjukkan bahwa tidak ada hubungan antara dukungan keluarga dengan tingkat kecemasan ibu hamil menghadapi proses persalinan di PMB Bd. C Kota Bandung.
\end{abstract}

Kata Kunci: Dukungan Keluarga, Tingkat Kecemasan Ibu Hamil, Proses Persalinan

\begin{abstract}
Anxiety facing the labor process topped the list most often experienced by pregnant women in the face of pregnancy and childbirth, one way to reduce anxiety in pregnant women is family support. Lack of family support that results in anxiety in pregnant women can result in babies born prematurely, children will have learning difficulties, hyperactivity, or even children become autistic This study aims to find out the relationship of family support with the level of anxiety pregnant women face the labor process in PMB Bd.C Bandung City. Research uses analytical survey research methods with a cross sectional approach, with accidental samplingsample techniques, which use questionnaireinstruments. The results showed that the average relationship of family support with the anxiety level of pregnant women facing labor in PMB Bd.C Bandung city with a value of $P$ value $>0.05$. This study shows that there is no relationship between family support and the level of anxiety pregnant women face the labor process in PMB Bd.C Bandung City.
\end{abstract}

Keywords: Family Support, Pregnancy Anxiety Levels, Childbirth 


\section{PENDAHULUAN}

Menjelang persalinan, ibu hamil membutuhkan ketenangan dalam menghadapi persalinan agar persalinan dapat berjalan dengan lancar. Saat-saat inilah ibu hamil sangar membutuhkan dukungan dari keluarganya (Na'im, 2012). Kurangnya dukungan keluarga yang mengakibatkan kecemasan pada ibu hamil bisa berakibat bayi lahir prematur, anak akan kesulitan belajar, hiperaktif, atau bahkan anak menjadi autisme. Ibu juga akan merasakan dampaknya kurang dukungan dari keluarga, seringkali ibu mengeluh mudah lelah, keluhan kurang tidur, rasa cemas akan menghadapi proses persalinan, ketakutan, mudah mimpi buruk dan gelisah (Tari, 2012).

Kekhawatiran dan kecemasan pada ibu hamil trimester III apabila tidak ditangani dengan serius akan membawa dampak berupa komplikasi dan pengaruh buruk terhadap fisik dan psikis yang keduanya saling terkait dan saling mempengaruhi. Jika kondisi fisiknya kurang baik, maka proses berfikir, suasana hati, tindakan yang bersangkutan dalam kehidupan sehari-hari akan terkena imbas negatifnya (Al-Atik, 2012).

Dukungan keluarga dapat berupa pemberian perhatian, dorongan, kasih sayang, barang, informasi dan jasa dari orang-orang terdekat suami/istri, orang tua, anak, dan orang terdekat lainnya sehingga penerima dukungan merasa disayangi dan dihargai. Adapun dukungan yang diberikan yaitu dukungan informasional, dukungan penilaian, dukungan instrumental (Mahmudah, 2010).
Dampak buruk dari kecemasan ibu hamil yaitu memicu terjadinya rangsangan kontraksi rahim. Akibatnya dapat mengakibatkan tekanan darah naik sehingga memicu terjadinya preeklamsi dan keguguran (Novriani, 2017). Kelahiran Bayi Berat Lahir Rendah (BBLR) dan bayi prematur juga merupakan dampak negatif dari kecemasan ibu hamil. Usia, paritas, tingkat pendidikan, dan pekerjaan menjadi faktor penyebab munculnya tingkat kecemasan pada ibu hamil (Handayani, 2015). Usia ibu akan berpengaruh terhadap kehamilan. Usia aman seorang ibu hamil diantara 20-35 tahun. Sedangkan tingkat pendidikan juga akan berpengaruh pada respon ibu dalam menghadapi sesuatu yang datang dari dalam diri ibu maupun dari luar atau lingkungan (Heriani, 2016).

Berdasarkan uraian latar belakang diatas, maka penulis merumuskan masalah penelitian ini yaitu bagaimana hubungan dukungan keluarga dengan tingkat kecemasan ibu hamil menghadapi proses persalinan. Adapun tujuan dari penelitian ini adalah Untuk mengetahui dukungan keluarga pada ibu hamil trimester III, untuk mengetahui tingkat kecemasan pada ibu hamil trimester III dan Untuk mengetahui hubungan dukungan keluarga dengan tingkat kecemasan ibu hamil.

\section{METODE PENELITIAN}

Penelitian ini menggunakan pendekatan cross sectional. Pupulasinya adalah ibu hamil trimester III yang melakukan pemeriksaan kehamilan di PMB Bidan C Kota Bandung pada bulan April 
2021 dan sampel diambil dengan teknik accidental sampling dimana didapatkan jumlah sampel 35 orang.Intrumen dukungan keluarga menggunakan kuesioner dan tingkat kecemasan menggunakan kuesioner berskala HARS (Hammilton Anxietas Rating Scale). Pengumpulan data didapatkan dari ibu hamil trimester III yang memeriksakan kehamilannya di PMB Bidan C Kota Bandung. Kemudian ibu hamil tersebut diberikan kuesioner yang berbentuk google form.

\section{HASIL PENELITIAN DAN}

PEMBAHASAN

\section{Hasil Penelitian}

Tabel 1

Distribusi Frekuensi Dukungan Keluarga pada Ibu Hamil Trimester III di PMB Bd. C

\begin{tabular}{lcc}
\hline Dukungan & Frekuensi & Persentase \\
\cline { 2 - 3 } \multicolumn{1}{c}{ Keluarga } & $\mathrm{F}$ & $\%$ \\
\hline Mendukung & 16 & 45,7 \\
Kurang & 19 & 54,3 \\
Mendukung & & \\
Total & 35 & 100 \\
\hline
\end{tabular}

Berdasarkan tabel 1 dapat diketahui bahwa dari keseluruhan responden berjumlah
35 ibu hamil trimester III, mayoritas tidak mendapat dukungan dari keluarga yaitu 19 responden (54,3\%), sedangkan 16 responden mendapat dukungan keluarga (45,7\%).

Tabel 2

Distribusi Frekuensi Kecemasan Menghadapi Persalinan Pada Ibu Hamil Trimester III di PMB Bd. C

\begin{tabular}{lcc}
\hline \multirow{2}{*}{ Kecemasan } & Frekuensi & Persentase \\
\cline { 2 - 3 } & $\mathrm{F}$ & $\%$ \\
\hline $\begin{array}{l}\text { Tidak ada } \\
\text { kecemasan }\end{array}$ & 20 & 57,1 \\
$\begin{array}{l}\text { Kecemasan } \\
\text { ringan }\end{array}$ & 13 & 37,1 \\
$\begin{array}{l}\text { Kecemasan } \\
\text { sedang }\end{array}$ & 2 & 5,7 \\
$\begin{array}{l}\text { Kecemasan } \\
\text { berat }\end{array}$ & 0 & 0 \\
\hline \multicolumn{1}{c}{ Total } & 35 & 100 \\
\hline
\end{tabular}

Berdasarkan tabel 2. dapat diketahui bahwa dari keseluruhan responden yang berjumlah 35 Ibu hamil trimester III, mayoritas tidak mengalami kecemasan terdapat 20 responden $(57,1 \%), 13$ responden $(37,1 \%)$ mengalami kecemasan ringan, 2 responden $(5,7 \%)$ mengalami kecemasan sedang, tidak ada responden yang mengalami kecemasan berat.

Tabel 3

Hubungan Antara Dukungan Keluarga Dengan Tingkat Kecemasan Ibu Hamil Menghadapi Persalinan di PMB Bd. C

\begin{tabular}{lccccc}
\hline \multicolumn{1}{c}{ Dukungan } & \multicolumn{4}{c}{ Tingkat Kecemasan } & \\
\cline { 2 - 5 } \multicolumn{1}{c}{ Keluarga } & Tidak ada & Ringan & Sedang & Berat & \\
\hline Mendukung & 10 & 6 & 0 & 0 & P Value \\
$\begin{array}{l}\text { Kurang } \\
\text { mendukung }\end{array}$ & 10 & 7 & 2 & 0 & 0,40 \\
\hline \multicolumn{1}{c}{ Total } & 20 & 13 & 2 & 0 & \\
\hline
\end{tabular}

Hasil uji Chi Square menunjukkan hasil $P$ Value 0,40 dengan taraf signifikan $\alpha$ $5 \%(0,05)$. Berdasarkan hasil tersebut bahwa nilai $P$ Value $0,40>\alpha(0,05)$, hal ini berarti tidak signifikan atau tidak ada hubungan antara dukungan keluarga dengan kecemasan menghadapi persalinan pada ibu hamil trimester III di PMB Bd. C Kota Bandung. 


\section{Pembahasan}

Dukungan keluarga merupakan sikap, tindakan penerimaan keluarga terhadap anggota keluarganya, berupa dukungan informasional, dukungan penilaian, dukungan instrumental dan dukungan emosional. Perhatian dan dukungan dari orang-orang terdekat sangat membantu dalam mengatasi kecemasan yang di alami ibu hamil karena perubahan-perubahan baik fisik maupun psikologis yang terjadi selama kehamilan. Dukungan dan kasih sayang dari anggota keluarga dapat memberikan perasaan nyaman dan aman ketika ibu hamil merasa takut dan khawatir dengan kehamilannya. Peran aktif keluarga untuk memberikan dukungan pada ibu yang sedang hamil berpengaruh terhadap kepedulian ibu atas kesehatan diri dan janinnya. Ibu hamil akan merasa lebih percaya diri, bahagia dan siap dalam menjalani proses kehamilan, persalinan, dan masa nifas (Nurwulan, 2017).

Berdasarkan hasil penelitian dukungan keluarga pada ibu hamil dalam menghadapi persalinan, ibu hamil yang mendapat dukungan keluarga sebanyak 16 responden (45,7\%) dan 19 responden (54,3\%) kurang mendapat dukungan keluarga. Variabel dukungan keluarga dalam penelitian ini terdapat empat bentuk dukungan, yaitu dukungan emosional, penilaian, instrumental, dan informasi. Hasil penelitian ini didapatkan data bahwa 18 responden (51,4\%) mendapatkan dukungan keluarga dalam bentuk dukungan emosional, sedangkan 17 responden $(48,6 \%)$ kurang mendapat dukungan keluarga dalam bentuk dukungan emosional. Pada instrument kuesioner penelitian dukungan keluarga pada bentuk dukungan emosional, item yang memiliki nilai terendah yaitu nilai unfavourable yang menyatakan bahwa keluarga kurang mengerti dengan keadaan saya yang akan mengalami persalinan. Dukungan keluarga yang bersifat positif kepada ibu hamil akan memberikan dampak positif terhadap pertumbuhan dan perkembangan janin, kesehatan fisik, dan psikologis bu. Bentuk dukungan keluarga tidak cukup dari sisi financial semata, tetapi juga berkaitan dengan cinta kasih, menanamkan rasa percaya diri kepada ibu hamil, sikap peduli dan perhatian (Rustikayanti, 2016: 45-46).

Kekhawatiran dan kecemasan yang teramat sangat bisa membuat otot-otot, termasuk otot di jalan lahir, bekerja berlawanan arah, karena dilawan oleh ibu yang kesakitan. Akibatnya, jalan lahir menyempit dan proses persalinan berjalan lebih lama dan sangat menyakitkan. Bahkan biasanya sampai terhenti. Dengan kondisi psikologi yang positif proses persalinan akan berjalan lebih mudah. kecemasan antenatal adalah masalah umum dan memiliki dampak serius pada kesejahteraan ibu. Temuan tersebut juga berkontribusi pada pemahaman kecemasan ibu dan memiliki implikasi untuk desain identifikasi yang efektif, pencegahan dan pengobatan masalah klinis yang signifikan (Chan, 2013: 330).

Keluarga dalam memberikan dukungan kepada ibu hamil dalam bentuk sering berkunjung, mendoakan keselamatan ibu dan bayi, menyelenggarakan ritual adat istiadat, menasehati tentang hamil dan 
melahirkan, mengantar ibu periksa, dan menemani ibu ketika melahirkan.

Terdapat 20 responden $(57,1 \%)$ tidak mengalami kecemasan, 13 responden $(37,1 \%)$ mengalami kecemasan ringan, 2 responden $(5,7 \%)$ mengalami kecemasan sedang, tidak ada responden yang mengalami kecemasan berat. kecemasan merupakan determinan penting dalam peningkatan rasa takut melahirkan. Salah satu hasil penelitian bahwa dengan meningkatnya jumlah kelahiran hidup, ketakutan akan kelahiran juga meningkat, situasi ini dapat dikaitkan dengan pengalaman kelahiran negatif sebelumnya dari wanita hamil (Erkaya, 2017: 237).

Kecemasan ringan cenderung terjadi pada ibu hamil yang didukung oleh keluarganya, selain itu juga karena faktor umur yang optimal untuk terjadi kehamilan dan persalinan, sehingga resiko yang mungkin dialami oleh ibu bersalin akan lebih sedikit, sehingga kecemasan yang dialami oleh ibu cenderung lebih ringan. Kecemasan sedang dan berat banyak dialami oleh ibu yang tidak didukung oleh keluarganya dan juga dipengaruhi oleh faktor umur yang dibawah 20 tahun, di mana usia tersebut sangat beresiko terjadi komplikasi selama persalinan, sehingga menimbulkan ketakutan tertentu dalam diri ibu. Responden yang mengalami kecemasan padahal telah mendapat dukungan keluarga disebabkan karena sifat ibu yang berbeda-beda dalam menanggapi perhatian dari keluarga.

Hasil menunjukkan bahwa sebagian besar keluarga tidak mendukung ibu hamil dalam menghadapi persalinan yaitu sebanyak
$54,3 \%$ dan hampir setengah dari ibu mengalami gejala kecemasan ringan dalam menghadapi persalinan yaitu $37,1 \%$. Hasil penelitian menunjukkan tidak ada hubungan dukungan keluarga dengan tingkat kecemasan ibu hamil menghadapi persalinan di PMB Bd. C Kota Bandung.

Ada beberapa faktor yang menyebabkan tidak ada hubungan antara dua variabel tersebut, yaitu terbiasanya masyarakat dengan hidup sendiri sebagaimana kehidupan di kota pada umumnya, ibu hamil terbiasa menjalani kehidupannya secara individual yang akhirnya kebiasaan tersebut terbawa pada saat kehamilannya dan akhirnya ibu lebih bisa mengontrol kecemasannya atau justru tidak merasakan kecemasan sedikitpun. Faktor lainnya yaitu besarnya peran paraji di daerah tersebut. Ibu hamil di daerah tersebut di awasi oleh paraji yang bekerjasama dengan bidan. Jadi ibu hamil lebih tenang karena paraji akan siap siaga jika ibu ada keluhan atau ada sesuatu yang membutuhkan bantuan. Hal ini sesuai dengan penelitian yang dilakukan di Kalimantan dimana kecemasan ibu hamil selain dipengaruhi oleh dukungan keluarga juga dapat dipengaruhi pendidikan tinggi, pendapatan tinggi, paritas, interaksi sosial, dan konseling (Simarmata, 2019: 287293).

Selain keluarga yang berpengaruh dalam persalinan adalah suami, hal ini juga sesuai dengan penelitian yang dilakukan di Surabaya dimana didapatkan bahwa dukungan suami secara signifikan menurunkan tingkat kecemasan ibu selama kehamilan pada trimester ketiga. Peran aktif 
Ira Kartika, Ida Suryani, Tiara Putri Claudya suami dalam memberikan dukungan kepada istri yang sedang hamil mempengaruhi kepedulian ibu terhadap kesehatannya dan janinnya. Selain itu, mereka akan merasa lebih percaya diri, bahagia, dan siap menghadapi kehamilan, persalinan, dan nifas (Abidah, 2021: 174-180).

Banyak wanita menderita ketakutan dan kecemasan selama kehamilan yang lebih mungkin karena kekhawatiran tentang kesehatan janin, perubahan dalam hubungan perkawinan dan masalah dalam menerima peran baru sebagai ibu. Kecemasan pada trimester ketiga tersebut lebih kepada persalinan, yang mungkin disebabkan oleh terbentuknya perubahan fisik yang berkaitan dengan kehamilan dan kelahiran anak yang tampaknya merupakan proses yang tidak terkendali. Menurut Organisasi Kesehatan Dunia, kehamilan remaja, kehamilan yang tidak diinginkan, riwayat kematian anak sebelumnya atau keguguran berulang, pertama kali hamil, kehamilan karena perkosaan, hubungan yang buruk dan tidak pantas dengan anggota keluarga dan wanita yang pernikahannya tidak dicatat atau diceraikan adalah di antara faktor risiko dalam pengembangan kecemasan selama kehamilan. Beberapa peneliti percaya bahwa tingkat kecemasan hanya tinggi pada trimester ketiga (Nekoee, 2015: 1-8).

\section{SIMPULAN}

Kesimpulan

\section{DAFTAR PUSTAKA}

Abidah, Anggraeni. (2021). Husband Support Correlates with Maternal Anxiety Levels During Pregnancy in The Third Trimester. Journal of Health Science.

Al-Atik. (2012). Synopsis Psikiatri. Jakarta: Bina Aksara,

Chan CY, Lee AM, Lam SK, Lee CP, Leung KY, Koh YW, Tang K (2013). Antenatal anxiety in the first trimester: Risk factors and effects on anxiety and depression in the third trimester and. Open Journal of Psychiatry, 3: 301310. Doi: 10.4236/ojpsych. 2013. 330 30

Erkaya E, Karabulutlu O, Calik KY. (2017). Defining Childbirth Fear and Anxiety Levels In Pregnant Women: Procedia - Social and Behavioral Sciences 237.

Handayani, Reska. (2015). Faktor-Faktor yang Berhubungan dengan Tingkat Kecemasan Menjelang Persalinan pada Ibu Primigravida Trimester III di Wilayah Kerja Puskesmas Lubuk Buaya Padang Tahun 2012. Ners Jurnal Keperawatan,

Heriani. (2016). Kecemasan dalam Menjelang Persalinan Ditinjau dari Paritas, Usia dan Tingkat Pendidikan. Jurnal Ilmu Kesehatan Aisyah.

Mahmudah, Siti. (2010). Psikologi Sosial

Sebuah Pengantar. Malang: UIN Malang Press 
Na'im, N. (2012). Hubungan dukungan keluarga dengan tingkat kecemasan ibu primipara menghadapi persalinan di Puskesmas Pamulangan Kota Tangerang Selatan. Fakultas Psikologi UIN.

Nekoee T, Zarei M (2015). Evaluation of the Anxiety status of pregnant women in third trimester of pregnancy and fear of childbirth and related factors. British Journal of Medicine \& Medical Study. 9(12): 1-8.

Nurwulan, D. (2017). Hubungan Dukungan Keluarga dengan Tingkat Kecemasan pada Pasien Pre Anestesi dengan Tindakan Spinal Anestesi. Politeknik Kesehatan Kementrian Kesehatan.

Novriani, Wira, Sari, Syafyu F. (2017). Dukungan Keluarga dengan Kecemasan Menjelang Persalinan Trimester III. Jurnal Ipteks Terapan.

Tari. M. (2012). Dukungan Psikologis dari Suami Saat Istri Hamil Sangat Penting. Dalam

http://kompasiana.com/post/read/4180 53/1/dukungan-psikologis-dari-suamisaat-istri-hamil-sangat-pentingmengapa.html.,. Diakses: Senin, 15 Maret 2021.

Rustikayanti, N.R, et.al. (2016). Perubahan Psikologis pada Ibu Hamil Trimester III. The Southeast Asian Journal of Midwifery

Simarmata,_Budihastuti,_Tamtomo. (2019).

Effect of Social Suport and Social Interaction on Anxiety Among Pregnant Women. Journal of meternal and child health. 
Ira Kartika, Ida Suryani, Tiara Putri Claudya 